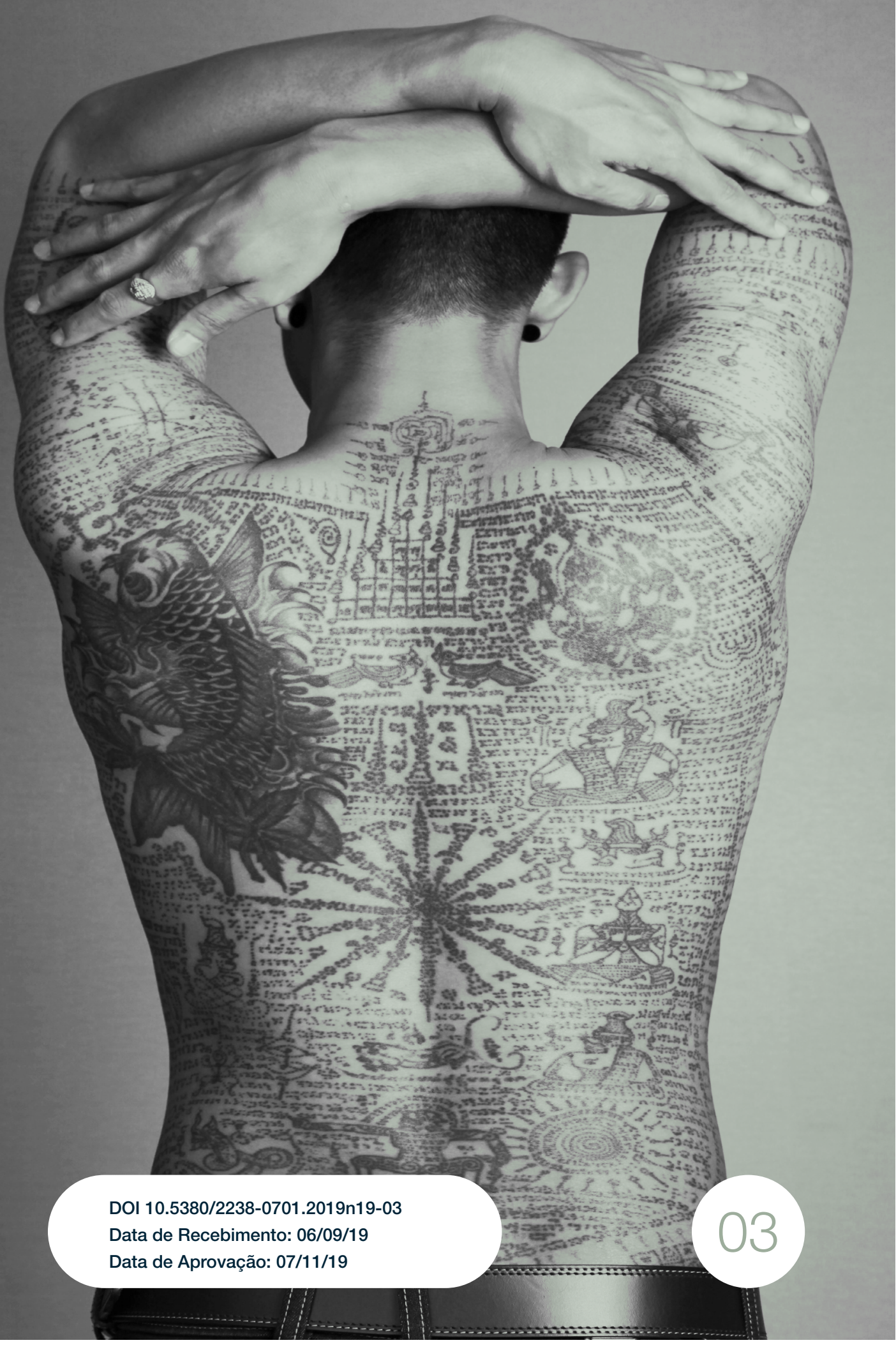


Narrativas da Pele: a Representação do Corpo e das Práticas Corporais na História Ocidental 


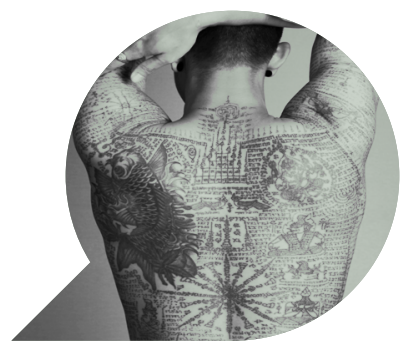

\title{
Narrativas da Pele: a Representação do Corpo e das Práticas Corporais na História Ocidental
}

\author{
Skin Narratives: The Representation of the Body and \\ Body Practices in Western History
}

Narrativas de la Piel: la Representación del Cuerpo y las Prácticas Corporales en la Historia Occidental

JÚLIA CABRAL RINALDI ${ }^{1}$

TARCISIO TORRES SILVA ${ }^{2}$

Resumo: Neste trabalho, observamos os diversos usos e significações de práticas corporais tais como a escarificação, flagelação e tatuagem ao longo da história ocidental. O intuito é identificar as relações entre os valores econômicos e sociais e as ações sobre o corpo. Notamos que noções como beleza e dor norteiam a corporeidade em sua relação com o espírito da época. Da mesma forma, auxiliam na compreensão dos estigmas criados em torno das modificações corporais e, por consequência, na ressignificação que tais práticas passam no mundo contemporâneo, contribuindo para a

\footnotetext{
1 Mestre em Linguagens, Mídia e Arte (PUC-Campinas), bacharel em Publicidade e Propaganda (PUC-Campinas). E-mail: juu.rinaldi@hotmail.com

2 Membro do corpo docente do mestrado em Linguagens, Mídia e Arte da PUC-Campinas. Professor pesquisador do Centro de Linguagem e Comunicação na mesma universidade. Doutor em Artes Visuais pela UNICAMP. E-mail: tarcisio.silva@puc-campinas.edu.br.
} 
complexidade nas narrativas em torno do corpo modificado e midiatizado de hoje.

Palavras-chave: Modificação corporal; Tatuagem; Corpo; Sacralização; Práticas corporais.

Abstract: In this paper, we aim at the various uses and meanings of body practices such as scarification, flogging, and tattooing throughout Western history. The aim is to identify the relationships between economic and social values and actions on the body. We note that notions such as beauty and pain guide corporeality in its relationship with the spirit of the time. In the same way, they help in understanding the stigmas created around body modifications and, consequently, in the resignification that such practices pass in the contemporary world, contributing to the complexity in the narratives around today's modified and mediatized body.

Keywords: Body modification; Tattoo; Body; Sacralization; Body practices.

Resumen: En este artículo, observamos los diversos usos y significados de las prácticas corporales, como la escarificación, la flagelación y los tatuajes a lo largo de la historia occidental. El objetivo es identificar las relaciones entre valores y acciones económicas y sociales en el cuerpo. Notamos que nociones como la belleza y el dolor guían la corporeidad en su relación con el espíritu de la época. Del mismo modo, ayudan a comprender los estigmas creados en torno a los cambios corporales y, en consecuencia, en la resignificación que tales prácticas pasan en el mundo contemporáneo, contribuyendo a la complejidad de las narrativas en torno al cuerpo modificado y mediatizado de hoy.

Palabras clave: Modificación corporal; Tatuaje; Cuerpo; Sacralización; Prácticas corporales. 


\section{Introdução}

Não se sabe ao certo quando as práticas de modificação corporal começaram a ser utilizadas na história. Para a tatuagem, existem duas hipóteses antropológicas: a de que ela teria sido praticada por um indivíduo e se espalhado por todos os continentes, ou a de que a prática teria surgido em diversos pontos do globo ao mesmo tempo, mas ainda não foi possível estabelecer uma origem exata (Ramos, 2001).

Os homens primitivos criavam desenhos em seu corpo "para marcar os fatos da vida biológica: seu nascimento, puberdade, reprodução, morte. Depois, os fatos da vida social: virar guerreiro ou sacerdote ou rei, casar-se, celebrar a vitória, identificar os prisioneiros, pedir proteção ao imponderável, garantir a vida do espírito antes, durante e depois do corpo" (MARQUES, 1997, p. 14). Nos estudos de Wohrlab et al. (2009), os autores defendem que as tatuagens eram altamente arriscadas e responsáveis pela transmissão de doenças em tribos. Por esse motivo, os indivíduos com muitas tatuagens eram considerados mais fortes e atraíam a atenção das mulheres e dos guerreiros inimigos. Vale ressaltar também a modificação corporal dos faraós egípcios. Seus deuses eram figuras híbridas de homens com animais e os faraós deveriam se aproximar dessas imagens. Por esse motivo, sendo homens ou mulheres, os faraós se pareciam com leões, com a aplicação de um falso cavanhaque que imitava a calda do animal (Ecce Hommo, 1999) e ornamentos que os retomassem.

Vamos direcionar este trabalho para a história ocidental, de forma a compreender melhor historicamente os diversos usos das marcas corporais ao longo do tempo, para poder localizar de maneira mais clara as diversas ressignificações pelas quais a modificação corporal e, mais especificamente, a tatuagem têm passado recentemente. Faremos isso através de uma revisão bibliográfica, colocando em diálogos autores que se preocuparam com a abordagem histórica e evolutiva que aqui propomos. Não se trata de dar conta completamente de um assunto tão vasto, muito menos de propor uma narrativa única para a complexidade que o tema envolve, mas contribuir para a análise acadêmica que se preocupa em localizar o debate contemporâneo sobre a modificação corporal e a tatuagem dentro de um complexo de significações que o inclui. 


\section{O corpo marcado na Antiguidade Clássica e na Idade Média}

A mitologia na Grécia antiga servia para explicar os mistérios da natureza e dos homens. O período foi marcado pela busca de verdades e justificativas para todos os eventos ocorridos. Os símbolos divinos eram deuses, semideuses ou heróis e apresentavam características físicas e emocionais humanas. Por esse motivo, o povo (homens livres) deveria cuidar de seu próprio corpo e se aproximar da perfeição física dos deuses. Os corpos masculinos eram exibidos publicamente: o ideal era ter corpos esculpidos, mostrando seus cuidados e seu empenho como guerreiro (Goffman, 2004).

Os gregos não acreditavam em vida após a morte e sua motivação era a vida terrena, vencer outros povos e o aprimoramento pessoal. O cuidado de si, enunciado por Foucault (2014), explica a relação do homem da Antiguidade na Grécia com seu próprio corpo e a necessidade de ter saúde para, assim, poder governar e vencer. O princípio da antiguidade clássica é de que apenas um corpo e mente saudáveis são capazes de transferir conhecimento e participar da política, como se fosse necessário cuidar de si para cuidar do outro.

Foi nesse período que o termo "estigma" foi criado. Para os gregos, o corpo perfeito era reflexo de uma mente superior e, por esse motivo, adotaram a prática de marcas corporais para identificar as pessoas que não faziam parte da sociedade ou apresentavam algum desvio de conduta ou uma degeneração moral, como os escravos, traidores ou criminosos. Era utilizada a escarificação com objetos cortantes ou o branding ${ }^{3}$, que marcava a pele com metal quente, deixando cicatrizes. $\bigcirc$ estigma foi utilizado por muitos séculos para marcação de pessoas que não pertenciam à sociedade e foi um dos fatos históricos que geraram preconceito aos praticantes da tatuagem do século XVIII, XIX e XX.

Os gregos, que tinham bastante conhecimento de recursos visuais, criaram o termo estigma para se referirem a sinais corporais com os quais se procurava evidenciar alguma coisa de extraordinário ou mau sobre o status moral de quem os apresentava. Os sinais eram feitos com cortes ou fogo no corpo e avisavam que o portador era um escravo, um criminoso ou traidor uma pessoa marcada, ritualmente poluída, que devia ser evitada; especialmente em lugares públicos. (GOFFMAN, 2004, p. 5)

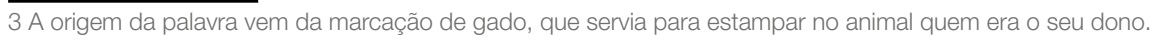


Utilizavam as emoções divinas para justificar problemas naturais e, por esse motivo, julgavam necessário agradar os deuses com homenagens, promovendo ritos e cultos diversos. Os jogos olímpicos são um exemplo: mais uma vez era necessário o aprimoramento físico do homem para ser vitorioso e agradar os deuses. Outra importância do cuidado com o corpo dos homens gregos, ou das pessoas que eles governavam, era para a realização de sacrifícios humanos para os deuses. A diferença entre os homens livres e os outros estratos sociais e os sacrifícios, além da busca por corpos perfeitos, seriam características que influenciariam as práticas corporais da sequente história ocidental.

Após a conquista romana e o início do Império Bizantino, essas características gregas influenciaram a cultura e, portanto, a Idade Média. O período baseia-se principalmente na crença cristã, com os ideais de vida após a morte, os conceitos de céu e inferno e, consequentemente, de bem e mal. É a partir da cultura cristã que surge também a ideia de pecado, geralmente pautada nos desejos carnais, e com ele a culpa e a auto penitência como práticas comuns. É também valorizado o sacrifício de Cristo pelo seu povo e propagada a ideia da importância da benevolência e do cuidado com o outro, apesar de as práticas de cuidado com o seu próprio corpo serem retomadas com determinada importância ao longo do período. No começo da era cristã, olhar para si tem uma conotação bastante egoísta (Duby, 2011).

O cristianismo prega uma busca pela vida após a morte, uma devoção para alcançar o paraíso e o medo de que as ações do homem o guiem para o inferno. Para que a humanidade não percorresse o caminho errado, com a influência do diabo, era necessário seguir uma cartilha e não cometer nenhum dos pecados listados - todos eles ligados ao corpo, dando início à preocupação da disciplina que contenha o indivíduo. Por esse motivo, o corpo, na Idade Média, é negado, considerado a incitação do mal e proibido. Os prazeres do corpo levam o homem a se desviar do caminho do paraíso.

De um lado, o perecível, o putrescível, o efêmero, o que deve voltar a ser pó, que, no entanto, é chamado a reconstruir-se para ressuscitar no último dia; do outro, o imortal. De um lado, o que é atraído para baixo pelos pesos, pelas opacidades das substancias carnais; do outro, o que aspira à perfeição celeste. O corpo, portanto, é considerado perigoso: é o lugar das tentações; dele, de suas partes inferiores, surgem naturalmente as pulsões incontroláveis; nele se manifesta o que depende do mal, concretamente, pela corrupção, pela doença, pelas 
purulências às quais nenhum corpo escapa; sobre ele se aplicam os castigos purificadores que expulsam o pecado, a falta. (DUBY, 2011, p. 541)

Importante destacar a contradição relativa às marcas corporais no período cristão. Quando não era a religião oficial e seus seguidores eram considerados pagãos, era comum criarem sinais de identificação, como a cruz, as letras IHS (sigla em latim de lesus Hominum Salvator, que significa "Jesus Salvador dos Homens"), o peixe, letras gregas ou o símbolo da igreja (MARQUES, 1997, p. 31). O imperador Constantino se colocou contrário à pratica de tatuagem e escarificação. Para ele, não se podia agredir a criação de Deus. Em 787, O papa Adriano I perseguiu a tatuagem. Essa limitação ocorria também em outras religiões. Maomé viria a julgar práticas corporais tribais, como alteração da pele, afiação dos dentes e a castração de escravos (MARQUES, 1997, p. 33).

Já no fim da Idade Clássica, o martírio de Cristo e seu corpo sacrificado passam a ser considerados belos, já que seu flagelo foi efeito de um ato de salvação da humanidade, para Umberto Eco "[...]a figura de Cristo era sofrida, apresentava os sinais da tortura, mas para salvar seu povo - o que torna o auto flagelo uma prática aceitável e o corpo mutilado por penitência não era considerado feio" (ECO, 2014, p. 133). Porém, nessa mesma obra, o autor menciona: "Dentre os séculos VI e VII, o belo se confundia com o útil, mesmo que a utilidade de um objeto fosse unicamente o enfeite. Para autores da época, um corpo mutilado ou deformado não poderia ser belo por não cumprir sua função de corpo" (ECO, 2014, p. 111).

Nesse sentido, o corpo que sofre é então belo e um reflexo da salvação, desde que o sofrimento não cause nenhuma debilidade, caso isso aconteça, o corpo será considerado feio nos padrões apresentados. Da mesma maneira que deformidades físicas de nascença eram escondidas do público. Por um tempo acreditou-se que essas falhas corpóreas eram um castigo por algum erro cometido pelos pais das crianças, da mesma forma as cicatrizes ou marcas no corpo eram consideradas provas da ligação com o demônio e com o pecado. O mártir passa a ser então considerado um exemplo a ser seguido por sua devoção e capacidade de abnegação do corpo e das dores por ele sentida, mas o corpo não deveria apresentar debilidades motoras ou funcionais. 
Além da questão do flagelo, ganha importância a herança clássica do embelezamento do corpo: "É incontestável, em todo caso, que a beleza física contou cada vez mais no decorrer desses séculos [XI-XIII] entre as armas que dispunha a identidade pessoal para afirmar-se no seio do coletivo" (DUBY, 2011, p. 546). A partir do século XII, as roupas passam a valorizar o corpo feminino e há uma preocupação em mostrar certos aspectos sociais, como a riqueza ou a virtuosidade da mulher. No final do século XIII, o corpo ganha uma dimensão razoavelmente importante: se Cristo ressuscitou em seu corpo, então o homem deve amar e respeitar o seu próprio corpo (DUBY, 2011, p. 543). O corpo passa a ser objeto de trabalho e ajuste (DUBY, 2011, p. 545). Ainda é necessária a cautela, pois o corpo permanece como fonte de pecado e deve ser mantido puro e imaculado.

Ainda nas questões relacionadas ao corpo, é relevante chamar atenção ao período da inquisição que começa no século XII e tem sua pauta nos tribunais no século XIV. Nesse período, começam a ser utilizadas práticas como a tortura e execuções públicas como punição do Estado: "A inquisição, inicialmente com o intuito de salvar a alma dos hereges, passou a empregar, mais tarde, a tortura e a fogueira como forma de punição, com autorização do Papa Inocêncio IV, em 1254" (BARBOSA; MATOS; COSTA, 2011, p. 27). As punições públicas e cruéis serão destacadas por Foucault (2014-2) como um dos motivos do desenvolvimento disciplinar:

No entanto, um fato é certo: em algumas dezenas de anos [fim do século XVIII e começo do século XIX], desapareceu o corpo suplicado, esquartejado, amputado, marcado simbolicamente no rosto ou no ombro, exposto vivo ou morto, dado como espetáculo. Desapareceu o corpo como alvo principal da repressão penal. (FOUCAULT, 2014-2, p. 13)

No período da Idade Média, o estigma corporal era considerado ligação com o diabo, as pessoas não se arriscavam a fazer tatuagens com medo da perseguição da Inquisição. Na França e na Itália, no período da Idade Média, os criminosos eram marcados em brasa, bem como os desvios morais, como no caso das prostitutas francesas com a marca da flor-de-lis. Ainda nesse período, a Inglaterra marcava os desvios com a sigla $\mathrm{BC}$, um sinal de falta de caráter. Por outro lado, os cavaleiros das 
cruzadas (séculos XI ao XIII) faziam registros religiosos e de batalhas em seus corpos. Entre os cristãos cópticos (russos, armênios, abissínios e sírios), a tatuagem também era bastante difundida (MARQUES, 1997, p. 35).

\section{A beleza e a dor do corpo no Renascimento}

Nos séculos XIV e XV, começam a surgir imagens da cultura cristã que tornaram a nudez parte de sua ideologia: "Adão, o glorioso, e Jesus, o supliciado, impõem ao povo fiel os dois termos da história da Criação e da Redenção, esplendor do corpo virgem e dor do corpo martirizado" (DUBY, 2011, p. 601). O corpo nu deixa de ser considerado um pecado desde que seja sacro. Entretanto, passa-se a entender o corpo despido; e, em alguns ambientes restritos, ele passa a ser permitido. Mais uma vez o corpo assume um papel de destaque, embora seja imprescindível lembrar que suas vontades são a origem de todos os pecados.

Sem dúvida, as formas novas da devoção, a partir do século XIV, conservam da tradição ascética a preocupação de pôr o corpo em seu lugar; mas, se a extrema santidade passa sempre pelo abandono de nosso despojo, se o movimento penitencial faz dos flagelantes especialistas do ferimento e da humilhação do corpo, a massa dos fiéis é convidada à imitação de Cristo, que não era um eremita, mas um homem no meio do povo. (DUBY, 2011, p. 611)

Como exemplo do sofrimento embelezado do cristianismo, utilizamos o quadro do século XV de Andrea Mantegna, St. Sebastian. O santo morreu ainda no período do Império Romano, 288 d.C. É lembrado por ser um mártir, e a maior parte das representações o retratam com três flechas cravadas em seu corpo por ordem do imperador romano Diocleciano como castigo por defender o cristianismo. No relato, o santo milagrosamente sobrevive às flechas. No quadro, podemos ver o corpo despido, com exceção do sexo, a expressão no rosto, indicando uma mudança nas tendências artísticas (após um período de negação da representação humana realista há uma retomada da forma clássica), além das ruínas gregas. No canto inferior esquerdo, é possível perceber que havia uma estátua grega, propondo uma sobreposição, como uma 
soberania, sobre a outra cultura (pagã).

Figura 1: St. Sebastian, Andrea Mantegna, 1480, Musée du Louvre, Paris.

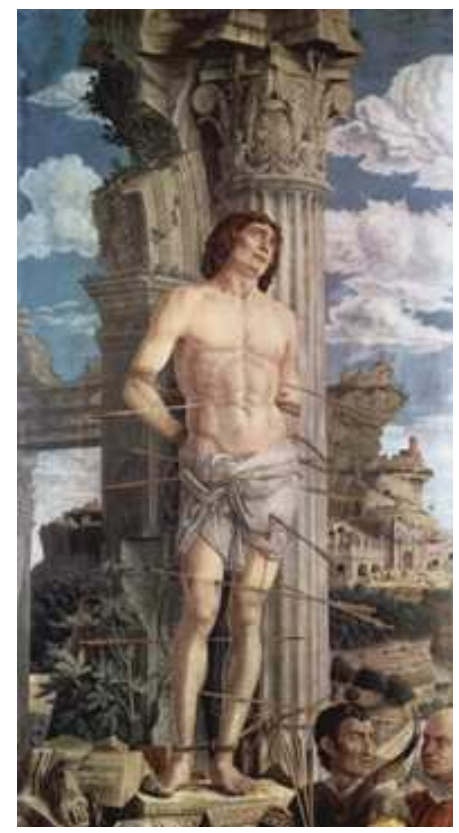

Fonte: Disponível em: <http://www.travelingintuscany.com/images/art/andreamantegna/andreamantegna088700.jpg >. Acesso em 04 nov. 2019.

Umberto Eco menciona uma tendência renascentista e pós-renascentista à "pulcrificação", ou seja, uma tendência a representar como belos: "fatos dolorosíssimos, de modo que, mais que o tormento, importa antes a força viril ou a doçura feminina com que os santos o enfrentam" (ECO, 2015, p. 56). Pensando ainda na concepção de Foucault, essa representação seria responsável por reafirmar a negação do sexo e, consequentemente, do corpo, como outra forma de sujeição, como se o castigo do corpo, a negação do prazer, o martírio fossem a maneira correta de se relacionar com seu próprio corpo.

Além da valorização do corpo como reservatório da alma e do empenho em lembrar do lugar desse invólucro com sua importância enquanto recipiente e perigo enquanto carnal, é também no século XIV que 
surge o grande tratado de Konrad von Megenberg, Das Buch der Natur (DUBY, 2011, p. 611), que sugere a necessidade de manter um corpo saudável para abrigar a alma. O texto propunha dietas, exercícios físicos, contato com a natureza. Nesse tratado, aparece a expressão até hoje utilizada: uma mente sã num corpo são (mens sana in corpore sano). Começa a existir, então, uma relação entre o bem-estar físico para gerar um bem-estar astral, retomando a cultura da época clássica.

Nesse período, não existia o conceito de privacidade, o indivíduo quase nunca estava sozinho e não exercia atividades de autorreflexão. Os prazeres carnais eram altamente condenados pela burguesia, mas era comum entre os trabalhadores do campo satisfazerem seus desejos ao ar livre durante o trabalho. Além disso, as famílias dos trabalhadores viviam sob o mesmo teto, dormiam no mesmo cômodo e muitas vezes no mesmo leito. Aparentemente, a crença cristã ainda não era suficiente para convencer toda a população, especialmente as parcelas que não pertenciam à aristocracia, qual era a maneira correta de agir e se comportar. Por esse motivo, além da doutrina cristã, que era por si só bastante severa e pregava o medo de um castigo, a herança das leis da antiguidade clássica vai colaborar, ao longo da Idade Média, com o desenvolvimento das estruturas disciplinares analisadas por Foucault (2017). A população não era apenas sujeitada pela religião, mas também por todas as outras estruturas de poder que moldavam a maneira de pensar, especialmente para o corpo. "O século XVII: seria o início de uma época de repressão própria das sociedades chamadas burguesas [...]" (FOUCAULT, 2017, p. 19).

Durante os séculos do Renascimento (XIV-XVII), a sociedade ocidental começou a se guiar pelo método científico, com uma supervalorização das matérias exatas e do racionalismo. Uma busca pelo conhecimento e pela descoberta das verdades também faz parte da herança clássica - essa busca da verdade era uma prática dos filósofos gregos. Foi nesse período que começou a haver uma maior preocupação com a liberdade do ser humano. O modo de pensar deixa de ser teocêntrico e começa a ser antropocêntrico. Consequentemente, há uma tendência ao cuidado do corpo. "Em uma sociedade que vai sustentar doravante a prevalência do humano e do terrestre sobre o divino, o obsceno transforma-se em orgulhosa afirmação dos direitos do corpo" (ECO, 2015, p. 142). 
Essas mudanças de costumes trazem de volta a beleza útil e prática nos séculos XVI e XVII. O corpo deve ser saudável e apto à prática de atividades produtivas, já que o período mostra sinais de mudança no sistema econômico. Na arte é crescente a representação do corpo real, um corpo vivo que sente, os artistas mostram uma preocupação em representar o corpo efêmero, que adoece. As representações e os estudos do corpo mostram os excretas físicos como algo grotesco, como se tudo que sai do nosso organismo fosse resto descartável e desvalorizado. Com isso, a população passa a ter uma repulsa de todo o resíduo corpóreo e das atividades relacionadas a eles, não se pode falar sobre os excrementos (ECO, 2015).

O corpo é valorizado, considerado belo, mas tudo que sai dele causa repulsa. Tudo aquilo que produz excretas passa a ser escondido, estritamente ligado ao âmbito privado. Para Foucault (2017), o fato de não poder falar do sexo, antes por ser considerado pecado, agora por gerar resíduos, mas, ao mesmo tempo, falar sobre ele de maneira velada e racional, gerou uma censura em toda a história ocidental que o precede. Nesse período, as concepções de belo e feio são consideradas indissociáveis. "O feio era uma curiosidade natural [...]" (ECO, 2014, p. 152). Mesmo os monstros eram considerados objeto de estudo, os estudiosos tentavam dissecar, observar, analisar, testar - tudo era feito para alcançar novas descobertas, cada vez tentando entrar mais fundo no corpo.

Havia uma relativização maniqueísta entre o bem e o mal, decorrente da valorização humanista. Antes havia um Deus, completamente bom, e um demônio, que representava todo o mal. Os homens e a vida não eram assim, então, se a visão teocêntrica começa a ser questionada, surge a representação e a valorização de um ser e uma sociedade que tem, ao mesmo tempo, atitudes boas e atitudes más. O conflito com o corpo começa, então, a ficar ainda mais complexo: um corpo útil para trabalhar, mas um corpo que padece e excreta substâncias repulsivas; um corpo que é belo por ser saudável e um corpo que é belo por ser vivo e representar algo natural, mesmo que seja a doença ou a morte; um corpo que sente, mas que deve ser reprimido e controlado.

Com a valorização do humano, algumas representações teológicas perdem valor, é o caso da figura do Satanás. Ainda há uma demonização nas representações, mas ela não está ligada às crenças religiosas 
e sim ao diferente. O inimigo, como era na Idade Clássica, é o outro, o estrangeiro. No período das Grandes Navegações (séculos XV ao XVII), a sociedade europeia entrou em contato com diversas culturas e costumes bem diferentes dos seus, alguns, inclusive, bastante repudiados. Os traços físicos dos povos encontrados nas viagens eram também bastante diferentes dos europeus, gerando representações do mau, do inimigo, como estereótipos de outras culturas.

A imagem do outro foi muito fortalecida com o avanço colonizador europeu, muitas culturas foram submetidas e praticamente desapareceram. A catequização em conjunto com as mudanças comerciais e judiciárias que foram impostas pela Europa dizimaram a prática da tatuagem e da escarificação por um longo tempo. O corpo marcado era considerado o corpo do escravo, como na Grécia. Também foi assim na França nos séculos XVII, XVIII e XIX, e na Inglaterra e nos Estados Unidos no século XX.

\section{O lluminismo e a separação entre corpo e mente}

É no século XVII que a obra de Descartes (1596-1650) promove a completa separação entre corpo e mente. Para o autor, a mente tem um potencial ilimitado, mas o corpo é perene. Essa separação entre corpo e alma também é uma herança clássica. Não é ainda uma desvalorização do corpo, existe a necessidade de cuidar do físico da melhor maneira possível para que ele não atrapalhe a mente, mas essa matéria que adoece, limita a grandeza da mente humana - considerada então como a melhor parte da humanidade e embasando as teorias iluministas e a futura depreciação do corpo.

Convencionalmente, o século XVIII é considerado o período iluminista, o Século das Luzes, em contraposição à era das trevas da Idade Média. O termo também se refere ao progresso e à tendência de considerar o homem um ser perfeito, próximo do que antes era a representação do divino, ou seja, brilhante. Vamos tentar considerar esse século como referência iluminista, mas muitas características do período já foram mencionadas. O que rege o pensamento iluminista é a progressão da burguesia. A proposta da elite europeia era reformar a sociedade, contrapondo o período medieval. O homem era considerado o centro, 
um ser com capacidade para melhorar o mundo e otimizar seu funcionamento. Por esse motivo, passa a existir uma tendência à dominação da natureza, esta precisa se tornar uma ferramenta para a soberania humana. A razão é o eixo que norteia esse século.

O lluminismo também critica o mercantilismo: é o momento do desenvolvimento burguês e das alterações das relações de troca. O mercantilismo era considerado incapaz de gerar grandes riquezas, já que não presumia acúmulo, apenas trocas, e esse sistema não era condizente com o desenvolvimento burguês. As instituições disciplinares ganham muita força no período, já que era necessário o controle do trabalhador e de seu corpo para que sua força de trabalho pudesse ser explorada. É também o século da Revolução Francesa e da Declaração dos Direitos do Homem e do Cidadão, que presumem uma liberdade até então denegada à população. Alguns autores, como Foucault (2017), consideram essa declaração uma compensação, como se o fato de doutrinar e encaixar os homens em espaços específicos só fosse aceito por uma sensação de liberdade que foi criada a partir de então.

Mas o corpo também está diretamente mergulhado num campo po-
lítico: as relações de poder têm alcance imediato sobre ele; elas o
investem, o marcam, o dirigem, o supliciam, sujeitam-no a trabalhos,
obrigam-no a cerimônias, exigem-lhe sinais. Este investimento político
do corpo está ligado, segundo relações complexas e recíprocas, à sua
utilização econômica; é, numa boa proporção, como força de produ-
ção que o corpo é investido por relações de poder e de dominação;
mas em compensação sua constituição como força de trabalho só é
possível se ele está preso num sistema de sujeição (onde a necessi-
dade é também um instrumento político cuidadosamente organizado,
calculado e utilizado); o corpo só se torna força útil se é ao mesmo
tempo corpo produtivo e corpo submisso. (FOUCAULT, 2014b, p. 29)

A impossibilidade de explicar tudo através da razão, a valorização da mente em detrimento ao corpo, a importância da liberdade do homem, mas a necessidade de moldá-lo para trabalhar na geração de renda, acabaram criando uma sensação de insatisfação e "[...] um mal-estar profundo em relação à época que invade não somente os artistas e intelectuais, mas todo o estrato burguês" (ECO, 2014, p. 313). Nas artes, é crescente o interesse na estética das ruínas, que gerava uma aproximação com a morte, com o corpo que envelhece, adoece, limita a mente. Esse sentimento de incerteza coloca fim ao Século das 
Luzes e dá início à era romântica e à valorização das emoções. Apesar do prestígio da ciência continuar presente no século XIX, passa a existir agora uma preocupação com os sentimentos humanos, supervalorizados, e um olhar para o eu. As últimas décadas do século XVIII e do século XIX são marcados pelo período do Romantismo, do homem romântico que transita entre: "Beleza e melancolia, coração e razão, reflexão e impulso" (ECO, 2014, p. 299). Fim da soberania francesa e início da potência britânica.

\section{A tatuagem no século XIX e início do século $X X$}

No início do século XIX, surge a corrente filosófica denominada Positivismo. Para August Comte (1830-42), um dos principais pensadores dessa corrente, o Positivismo surge como reflexo da crise da Idade Média que, como vimos até aqui, tornou-se insustentável para o pensamento da sociedade ocidental. Além disso, trata-se de um desenvolvimento sociológico do lluminismo, que propõe uma negação a tudo que é teológico e metafísico, e a qualquer fato que não possa ser explicado através do conhecimento científico. Os positivistas contrapunham inclusive o racionalismo, já que a busca por causas ou efeitos que não pudessem ser comprovadas pela ciência seriam consideradas buscas sem sentido. $O$ positivismo também é um reflexo do desdobramento do desenvolvimento industrial e da necessidade da época de valorização humana, já que aqui começam as preocupações com o desenvolvimento tecnológico e o questionamento sobre as condições de trabalho, que são discutidas até os dias de hoje.

Comte propõe um método positivista (Comte, 1978). Para ele, quaisquer acepções idealistas ou racionalistas iriam contra o natural. Acredita que não existe motivo para justificar fenômenos, o único método científico capaz de produzir um entendimento da sociedade seria a observação. Estabelece uma conceituação baseada em sua Lei dos três estados, que propõe estágios pelos quais a sociedade se desenvolve: primeiro o estado teológico baseado em deuses e com uma busca por semelhança a essas entidades ou por um paraíso; o segundo estado seria o metafísico, uma transição, ainda busca respostas através do uso da razão, apresenta também uma busca por algo que transpõe o humano; e o terceiro 
estado é o positivo, sem busca por razões e apenas se apoiando na observação de fatos, a ideia é um entendimento do concreto.

Seguindo essa lógica progressiva dos três estados, Comte (1852) propõe uma religião humana como um estágio final das religiões que vieram antes. Ao contrário das crenças anteriores, a religião humana se baseia no concreto, sem aspiração por crenças e baseada no conhecimento científico. Seu principal objetivo era a regeneração da sociedade e da moral de seus indivíduos. Essa nova religião tem como base práticas das religiões que a precedem: seu deus é a humanidade, seus santos, pessoas que trouxeram algum progresso relevante para esse deus, além disso, apresentava um calendário próprio e propunha hábitos, cultos e uma doutrina.

O período também foi responsável pela relação negativa dos países de tradição católica à tatuagem. Um exemplo é o autor italiano Cesare Lombroso que utilizou a tatuagem, dentre outros traços físicos, para caracterizar pessoas moralmente degeneradas em uma obra ligada ao positivismo e à antropologia criminal. Em seu livro de 1876, O homem criminoso, o autor afirma que a "tatuagem é um sinal de inferioridade mental praticado por raças inferiores" (MARQUES, 1997, p. 63). Em ECO (2015, p. 16), lemos ainda que Lombroso "tentava demonstrar que os traços da mente criminosa estavam sempre associados a anomalias somáticas. [Ele] não chegava à simplificação de dizer que quem é feio é sempre delinquente, mas associava estigmas físicos a estigmas morais, como argumentos que se pretendiam científicos".

A tatuagem era símbolo do estigma moral, por esse motivo, era comum ver prisioneiros, piratas, marinheiros, prostitutas que portavam tatuagens. Nesse grupo, também estavam artistas circenses que se tornavam atração por seus corpos cobertos de desenhos. Dentre os diversos exemplos desse grupo, vamos citar Frank Howard (1857-1920), conhecido como "o homem tatuado original", que, após uma turnê com o circo Barnum \& Bailey, no início dos anos 1890, com a sua irmã, Annie Howard, decidiu abrir um estúdio de tatuagem em Boston, que se estabeleceu como um dos maiores estúdios da costa leste americana. 
Figura 2: Frank Howard, final da década de 1890.

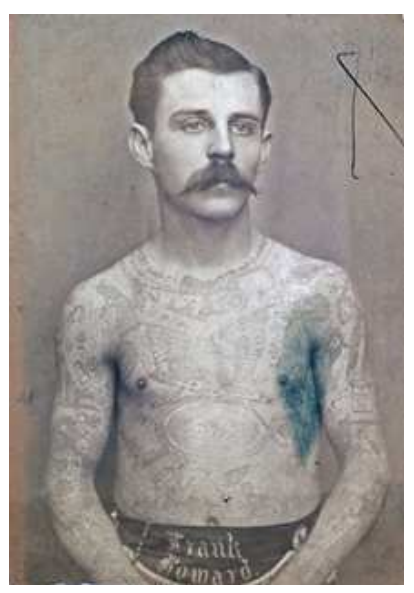

Fonte: Disponível em: <http://68.media.tumblr.com/8c7f842c50bb49aba09ead7e7ca02205/tumblr_nltsnqjk801r65d8u01_1280.jpg>. Acesso em 06 nov. 2019

Mas foi também no período vitoriano europeu (1837-1901) que a tradição militar dos reis e da nobreza fizeram com que essa parcela da população entrasse em contato com a prática da tatuagem, inclusive com os tatuadores que faziam os desenhos nos navios, e com diversos estilos, em especial o Japonês, após a abertura do país. O estilo asiático de tatuagem foi altamente valorizado na Europa, influenciando os desenhos modernos. Sailor Jerry ${ }^{4}$ foi um famoso tatuador de marinheiros e aprendeu a tatuar primeiramente com a técnica hand-poke tattoo ${ }^{5}$. Seu estilo de arte foi bastante influenciado por suas viagens ainda na Marinha norte-americana ao Sudeste Asiático e teve grande influência no estilo de tatuagem moderno.

Para ilustrar, apresentamos os pôsteres circenses, do início do século XIX, que anunciavam os sideshows, também conhecidos como freak shows. Geralmente esse tipo de show apresentava pessoas consideradas aberrações, com alguma anomalia genética marcante, como maior ou menor número de membros no corpo, excesso de pelos, tamanho do crânio diferente do convencional, ou, nesse caso, tatuagens

4 Norman Keith Collins (1911-1973), artista tatuador, marinheiro e músico norte-americano.

5 Técnica que não utiliza a máquina para execução de tatuagens. 
que cubram todo o corpo:

Figura 3: Vintage Circus Sideshow - reimpressão de poster, originalmente desenvolvido e impresso na Alemanha, La Bella Angora, 1906.

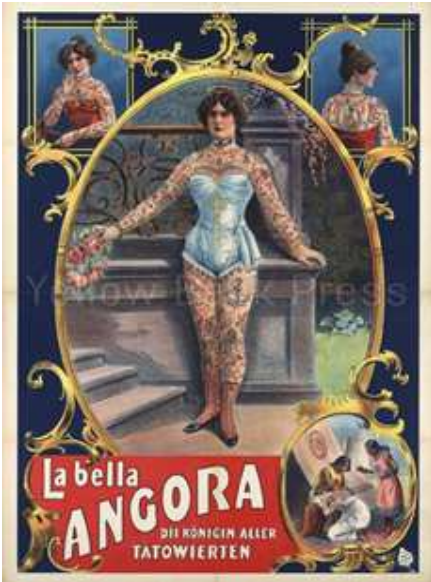

Fonte: Disponível em: <https://cdn.shopify.com/s/files/1/0653/4479/products/labellaangora18x24_1024x1024.jpg?v=1484439961>. Acesso em 06 nov. 2019.

Figura 4: Vintage Circus Sideshow - reimpressão de poster, originalmente desenvolvido e impresso na Alemanha, Don Manuelo, 1908.

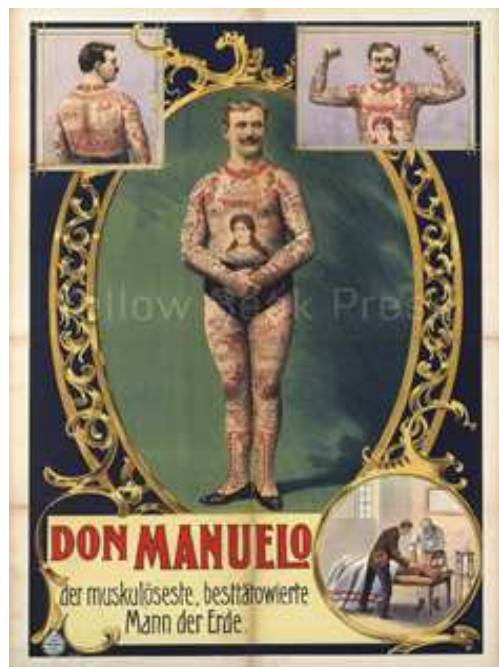

Fonte: Disponível em: <https://cdn.shopify.com/s/files/1/0653/4479/products/donmanuelo- 
18x24_1024x1024.jpg?v=1484440217>. Acesso em 06 nov. 2019.

A relação simbólica das práticas corporais vai mudar bastante ao longo do século XX. O movimento primitive moderns é bastante significativo nesse sentido. Ele teve início com Fakir Musafar - xamã, artista, piercer e modificador do corpo, conhecido por sua extensa pesquisa sobre modificação corporal e diretor do Fakir Body Piercing \& Banding Intensives, único curso da área no mundo; Fakir também deu nome aos jogos corporais - que, influenciado pelos hábitos de uma reserva indígena, buscou entender e conhecer as técnicas de modificação corporal e praticá-las em seu próprio corpo. O termo "modern primitives" foi utilizado por ele em 1979. O termo era relacionado às pessoas que faziam parte de sociedades modernas, mas adotavam práticas primitivas. Ele começou suas experiências de modificação aos 12 anos (1942) com um espartilho, e aos treze anos colocou seu primeiro piercing no prepúcio.

Figura 5: Fakir Musafar - waist training.

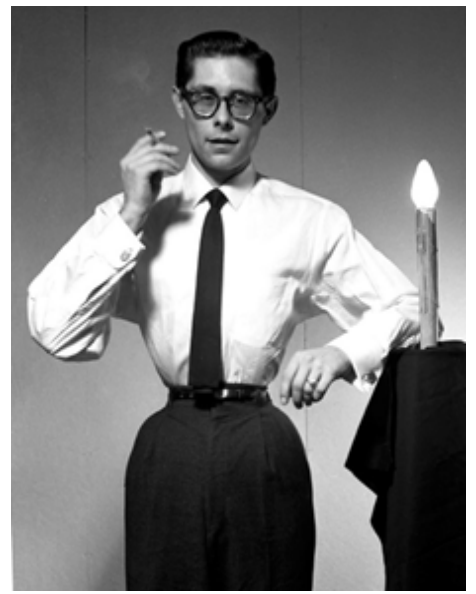

Fonte: Disponível em: <http://www.fakir.org/images/GentlemanW.jpg>. Acesso em 06 nov. 2019.

Para Fakir, as regras eram uma restrição de sua liberdade e alteridade. Ele praticava "jogos corporais" para se aproximar da magia. Para ele, esse era o meio de controlar o mundo. Suas experiências buscavam aproximá-lo da morte e da espiritualidade: Fakir explica suas práticas como uma transcendência, uma busca do êxtase, e, para alcançar o eu ou uma verdade espiritualizada, torna-se necessária a dor (DOSSIN; RAMOS, 2008, p. 7). Ele também apresentava uma explicação para essa 
sua relação com a dor. Para ele, a dor que era esperada e muitas vezes procurada não era ruim para o ser. Quando ele se submete a alguma dor extrema, se aproxima de estados de espírito que transcendem a carne.

Os primitivos modernos não são assim nominados unicamente por suas práticas ritualísticas, mas também por associações primitivas com a sexualidade não repreendida pelo catolicismo e uma tentativa de existir num molde anterior à condição social (ROSENBLATT, 1997, p. 322). As modificações em si não fazem do indivíduo um moderno primitivo, pois, segundo as doutrinas do movimento, ele precisaria ter convicções que confrontassem o mercado para isso. Provavelmente esse é o ponto que afasta os indivíduos que praticam a modificação corporal unicamente como forma de expressão, arte ou adorno dos modernos primitivos, pois a body modification praticada nos dias de hoje, que inclui práticas das mais diversas, não necessariamente nega o sistema e seus participantes não buscam somente viver marginais a ele.

\section{Conclusões}

Neste trabalho, observamos alguns pontos que tem influência no imaginário corporal contemporâneo. Entre elas, destacamos a busca por um físico perfeito e saudável, a repreensão e o pudor com o corpo herdados da cultura cristã, a prática de flagelos corporais como penitência e a relação dos prazeres do corpo com o pecado. A supervalorização da mente humana e a preocupação médica com a manutenção da saúde corpórea a todo custo, o enaltecimento humanista e a noção de superioridade e importância da espécie humana.

Além disso, mostramos que as disciplinas agem sobre a domesticação desses corpos, estando as práticas corporais sob efeito dessas forças de controle. Como coloca Foucault (2014b, p. 143), a disciplina "individualiza os corpos por uma localização que não os implanta, mas os distribui e os faz circular numa rede de relações". É essa rede que procuramos mostrar neste trabalho, com permissões e repressões que atuam sobre a modificação do corpo.

As influências históricas ocidentais contribuem para compreendermos as múltiplas dimensões que se estabelecem sobre os significados da modificação corporal no mundo contemporâneo. Ao longo da 
história, percebemos diferentes narrativas criadas a partir das marcas sobre a pele. Elas davam conta de compreender o contexto cultural do qual aquelas marcas faziam parte, além de compreender o lugar e os valores sobre os corpos na época.

Tais narrativas, assim como as diferentes simbologias que fazem parte da cultura da tatuagem contemporânea, permeiam o imaginário dos indivíduos e destes com seus próprios corpos, o que faz com que as práticas de modificação corporal hoje estejam carregadas de significados que não se prendem só ao contemporâneo, mas que se alimentam de práticas variadas da história da cultura. São marcas de um tempo com continuidades e rupturas, em constante revisão com relação ao seu contexto original.

As modificações atuais têm uma relação muito mais estreita com a pós-modernidade do que com a tradição dos primitivos modernos. Ainda assim, traços de simbologias passadas permanecem entremeados pelas práticas modernas, numa sobreposição de semioses que incluem o imaginário simbólico e histórico em torno das práticas corporais, como aqui mostramos, e o processo de midiatização por que passa a exibição do corpo hoje.

\section{REFERÊNCIAS}

BARBOSA, M. R.; MATOS, P. M.; COSTA, M. E. Um olhar sobre o corpo: o corpo ontem e hoje. Psicologia \& Sociedade, 2011, 21(1), 24-34.

COMTE, Auguste. Comte: os pensadores. São Paulo, Câmara Brasileira do Livro, 1978.

DOSSIN, Francielly Rocha; RAMOS, Célia Maria Antonacci. Corporalidades no Urbano Contemporâneo: A Body Modification e os Modern Primitives. Anais do IV Enecult (Encontro de Estudos Multidisciplinares em Cultura). Salvador: Faculdade de Comunicação/UFBa, 2008.

DUBY, Georges. A História da Vida Privada: Da Europa Feudal à Renascença. São Paulo: Editora Schwarcz, 2011.

ECCE HOMO: moda e vestuário. Direção: Pierre Lawrence. Fotografia: Alain Bisson. 52 min, colorido, 1999. Disponível em <https://www.youtube.com/watch?v=iZi8h_Zl37s> Acesso em: 25/04/2017.

ECO, Umberto. História da Beleza. Rio de Janeiro: Editora Record, 2014.

História da Feiura. Rio de Janeiro: Editora Record, 2015.

FOUCAULT, Michel. História da sexualidade 1: a vontade de saber. Rio de Janeiro/São Paulo: Editora Paz e Terra, 2017. 
História da sexualidade 3: o cuidado de si. Rio de Janeiro/São Paulo: Editora Paz e Terra, 2014a.

Vigiar e punir: o nascimento da prisão. Petrópolis, RJ: Editora Vozes, 2014b.

GOFFMAN, Erving. Estigma: notas sobre a manipulação da identidade deteriorada. 2004. Disponível em < https://edisciplinas.usp.br/pluginfile.php/92113/mod_resource/content/1/Goffman\%3B\%20Estigma.pdf>. Acesso em 05 set. 2019.

MARQUES, Toni. O Brasil tatuado e outros mundos. Rio de Janeiro: Editora Rocco, 1997.

RAMOS, Célia Maria Antonacci. Teorias da Tatuagem. Florianópolis: Udesc, 2001.

ROSENBLATT, Daniel. The Antisocial Skin: Structure, Resistance, and "Modern Primitive" Adornment in the United States. Blackwell Publishing on behalf of the American Anthropological Association. Disponível em: < https://indigenouscreativeexpression. wikispaces.com/file/view/Modern+Primitive.pdf> Acesso em: 09 mar. 2018.

WOHLRAB, Silke; FINK, Bernhard, KAPPELER, Peter M; BREWER Gayle. Perception of human body modification. Personality and Individual Differences, 46(2):202-206, 2009. Disponível em: <https:// www.psych.uni-goettingen.de/de/biopers/publications_department/WohlrabEtAl2009a>. Acesso em 05 set. 2019.

Data do recebimento: 06 setembro 2019

Data da aprovação: 07 novembro 2019 


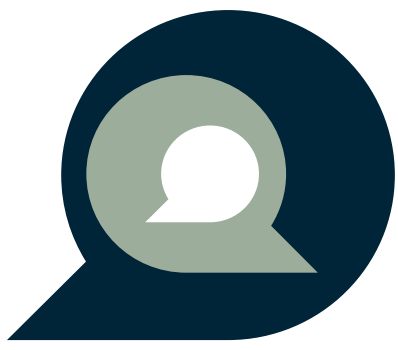

